\title{
Replacement of soybean meal by cottonseed meal $38 \%$ in multiple supplements for grazing beef heifers
}

\section{Lívia Vieira de Barros ${ }^{1}$, Mário Fonseca Paulino², Sebastião de Campos Valadares Filho², Edenio Detmann ${ }^{2}$, Felipe Gomes da Silva ${ }^{1}$, Ériton Egidio Lisboa Valente ${ }^{1}$, Sidnei Antonio Lopes $^{1}$, Leandro Soares Martins ${ }^{3}$}

${ }^{1}$ DZO/UFV - Viçosa, MG

2 DZO/UFV - Viçosa, MG. Pesquisador INCT-CA.

${ }^{3}$ DZO/UFV - Viçosa, MG. Bolsista de Iniciação Científica do INCT de Ciência Animal.

ABSTRACT - The objective of this work was to evaluate the effect of using multiple supplements with different levels of cottonseed meal 38\% on intake, total apparent digestibility of dietary components, efficiency of microbial synthesis and productive performance of beef heifers in Brachiaria decumbens pasture during the rainy season. It was used 25 Nellore heifers and 10 crossbred heifers with predominance of Zebu breed at 16 months of age and with $249.8 \pm 0.6 \mathrm{~kg}$ of body weight. It was used a complete random experimental design with five treatments and seven replicates. Supplements contained approximately $30 \%$ of crude protein (CP) and soybean meal replaced by cottonseed meal 38\% at the levels 0; 33; 67 and $100 \%,\left(\mathrm{CS}_{0}\right.$, $\mathrm{CS}_{33}$, $\mathrm{CS}_{67}$ and $\mathrm{CS}_{100}$, respectively) evaluated in relation to a control group, which received only mineral mixture (MM) ad libitum. Daily weight gain was 397, 546, 570, 525 and 542 g, respectively, for the groups MM, CS ${ }_{0}, \mathrm{CS}_{33}, \mathrm{CS}_{67}$ and $\mathrm{CS}_{100}$. There was no effect of the levels of cottonseed meal $38 \%$ on daily weight gain, which differed among animals fed supplement and control group, however. Intakes of crude protein and non-fibrous carbohydrates (NFC) in $\mathrm{kg} /$ day were greater in groups under supplementation. Coefficients of total apparent digestibility of CP and NFC were greater in animals fed supplements in relation to the control group. Increase on the replacement level of soybean meal by cottonseed meal had a positive linear effect on coefficients of total apparent digestibility of DM, organic matter and CP. There was no difference on microbial efficiency, expressed as g of crude protein per kg of TDN consumed by the animals under supplements and the ones of the control group, neither it was observed difference among levels of replacement of soybean meal by cottonseed meal. The use of cottonseed meal 38\% replacing soybean meal in the diet does not harm performance of grazing beef heifers.

Key Words: Brachiaria decumbens, nutritional parameters, supplementation

\section{Substituição do farelo de soja por farelo de algodão $38 \%$ em suplementos múltiplos para novilhas de corte em pastejo}

\footnotetext{
RESUMO - Objetivou-se avaliar o efeito do uso de suplementos múltiplos com diferentes níveis de farelo de algodão 38\% o sobre o consumo, a digestibilidade aparente total de componentes da dieta, a eficiência de síntese microbiana e o desempenho produtivo de novilhas de corte em pastagem de Brachiaria decumbens no período das águas. Utilizaram-se 25 novilhas nelores e 10 novilhas mestiças com predominância de sangue zebu com 16 meses idade e 249,8 \pm 0,6 kg de peso corporal. O delineamento foi inteiramente casualizado com cinco tratamentos e sete repetições. Os suplementos continham aproximadamente $30 \%$ de proteína bruta (PB) e substituição do farelo de soja pelo farelo de algodão 38\% nos níveis de 0 ; 33; 67 e $100 \%$, ( $\mathrm{CS}_{0}, \mathrm{CS}_{33}, \mathrm{CS}_{67}$ e $\mathrm{CS}_{100}$, respectivamente), avaliados em relação a um grupo controle, que recebeu apenas mistura mineral ad libitum (MM). O ganho médio diário foi 397, 546, 570, 525 e 542 g, respectivamente, para os grupos $\mathrm{MM}, \mathrm{CS}_{0}, \mathrm{CS}_{33}, \mathrm{CS}_{67}$ e $\mathrm{CS}_{100}$. Não houve efeito dos níveis de farelo de algodão $38 \%$ sobre o ganho médio diário, que diferiu, no entanto, entre os animais que receberam suplemento e os do grupo controle. Os consumos em $\mathrm{kg} / \mathrm{dia}$ de proteína bruta e carboidratos não-fibrosos (CNF) foram maiores nos grupos sob suplementação. Os coeficientes de digestibilidade aparente totais da PB e dos CNF foram maiores nos animais que receberam suplemento em relação aos do grupo controle. O aumento do nível de substituição do farelo de soja pelo farelo de algodão teve efeito linear positivo sobre os coeficientes de digestibilidade aparente totais da MS, matéria orgânica e PB. Não houve diferença na eficiência microbiana, expressa em g de proteína bruta por kg de NDT consumido entre os animais sob suplementados e os do grupo controle, assim como não foi observada diferença entre os níveis de substituição do farelo de soja pelo farelo de algodão. O uso de farelo de algodão $38 \%$ em substituição ao farelo de soja na dieta não prejudica o desempenho de novilhas de corte em pastejo.
}

Palavras-chave: Brachiaria decumbens, parâmetros nutricionais, suplementação 


\section{Introduction}

One way of improving productive indices of the bovine production system is by supplementation of bovines on pasture, which is the alternative that most increase as an strategy for increase of productivity nowadays (more than $2000 \%$ from 1991 to 2006) (ANUALPEC, 2007). Despite of the fact that both energetic and protein substrate can be introduced in the system through supplementation, most of the energetic substrates related to neutral detergent fiber potentially digestible are not used because of deficiency of microbial enzymatic systems in the ruminal environment (Paulino et al., 2006). So, primordial supplementation with nitrogen compounds increase microbial activity by providing increase of intake and extraction of energy from forage (NDFpd fraction), as a response to the stimulus verified on rate and extension of NDFpd degradation, with a consequent reduction of ruminal fullness effect (Costa et al., 2008).

Supply of supplementation of energy, cannot alone eliminate both energetic and protein deficiencies because it does not meet completely the last one. However, it is needed to recognize the interactive system of the diet (Detmann et al., 2008) to explore the benefic effect and /or minimize the deleterious effects of interaction among the diet constituents.

Another important factor is the economical feasibility of supplementation during the season favorable to forage growth. Accordinlgy, it is important to consider the use of low cost supplements, in which waste and co-products of agro industrial origin are an option for reducing the cost of supplementation and also because they do not compete with monogastric feeding.

Cotton meal is an agro industrial co-product that can be used in ruminants feeding, which is regularly used as partial or total substitute for soybean meal. Cotton is the second most important source of protein supplement available for animal feeding, exceeded only for soybean (Nuvital, 2009).

Therefore, the present research was carried out aiming to evaluate the need of supplementation and the effect of replacement of soybean by cottonseed meal 38\% in multiple supplements for beef steer under pasture during the rainy season on the productive performance, on the nutritional parameters and on the efficiency of microbial synthesis.

\section{Material and Methods}

The experiment was carried out in Setor de Bovinocultura de Corte in Departamento de Zootecnia at Universidade
Federal de Viçosa from January to March 2009, totaling 84 days divided in three experiment periods.

During the experimental period, the observed averages for maximum temperature $\left({ }^{\circ} \mathrm{C}\right)$, minimum temperature $\left({ }^{\circ} \mathrm{C}\right)$ and rainfall precipitation were 28.8; 19.5 and $235.1 \mathrm{~mm}$ respectively.

It was used 25 Nellore heifers and 10 crossbred heifers with predominance of Zebu breed at 16 months of age and $249.8 \pm 0.6 \mathrm{~kg}$ of initial weight divided in 5 supplements. The experimental design was a complete random one with five supplements and seven replicates in each treatment.

The experimental area assigned for the animals were composed by five 2.5 ha paddocks with Brachiaria decumbens grass provided with covered drinkers and feeders.

It was evaluated four supplements (Table 1) with approximately $30 \%$ (\%MS) of crude protein. Soybean meal (SM) was replaced by cottonseed meal $38 \%$ at the levels of 0, 33, 67 and $100 \%$ for the $\mathrm{CS}_{0}, \mathrm{CS}_{33}, \mathrm{CS}_{67}$ and $\mathrm{CS}_{100}$ supplements, respectively, plus a control group in which animals received only mineral mixture ad libitum. The supplements were supplied at the quantity of $1.0 \mathrm{~kg}$ of supplement/animal/day, urea was added to all supplements to keep the supplements as isoprotein.

The supplement was supplied daily around 10 a.m. in common feeder, with 2 meters in length and access on both sides to provide simultaneous access of all the animals.

At the beginning of the treatment, all the animals were submitted to ecto and endoparasites control and during the experimental period, it was carried out supplements against ticks and horn flies and when it was needed.

Animals were weighted after fast at the beginning and end of the experiment. Every 14 days, animals were rotated among the paddocks aiming at minimize possible interferences on the results due to differences among paddocks (pasture availability, watery and trough localization, relief, shading etc).

Table 1 - Percentage composition of supplements, based in natural matter

\begin{tabular}{|c|c|c|c|c|c|}
\hline \multirow[t]{2}{*}{ Ingredient (\%) } & \multicolumn{5}{|c|}{ Supplement } \\
\hline & $\mathrm{MM}$ & $\mathrm{CS}_{0}$ & $\mathrm{CS}_{33}$ & $\mathrm{CS}_{67}$ & $\mathrm{CS}_{100}$ \\
\hline Mineral mixture $^{1}$ & 100.0 & 6.0 & 6.0 & 6.0 & 6.0 \\
\hline Ground sorghum grain & - & 20.5 & 20.5 & 20.5 & 20.5 \\
\hline Ground corn grain & - & 20.5 & 20.5 & 20.5 & 20.5 \\
\hline Soybean meal & - & 50.0 & 33.5 & 16.5 & - \\
\hline Cottonseed meal 38\% & - & - & 16.5 & 33.5 & 50.0 \\
\hline Urea/SA (9:1) & - & 1.0 & 1.5 & 2.5 & 3.0 \\
\hline Wheat meal & - & 2.0 & 1.5 & 0.5 & - \\
\hline
\end{tabular}

1Percentage composition: bicalcium phosphate - 50.00; sodium chloride 47,775 ; zinc sulphate -1.40 ; copper sulphate -0.70 ; cobalt sulphate -0.05 ; potassium iodate -0.05 and sodium selenite -0.025 . 
The total weight gain was quantified by subtracting the final weight by the initial, in which daily weight gain was the ratio of total weight gain by number of experiment days (84), after fourteen days of adaptation to diet and place of trial.

On the fourteenth day of every 28-day cycle, forage sample collection was performed in the different paddocks through cutting at 5 centimeters above ground of four areas delimitated by a $0.25 \mathrm{~m}^{2}$ metal square, randomly chosen in each experimental paddock. After collection, each sample was weighted and homogenized and from them a compound sample was taken: one for evaluation of total dry matter availability and potentially digestible dry matter. After being separated, samples were oven-dried $\left(65^{\circ} \mathrm{C}, 72\right.$ hours) and then analyzed for the total availability of pasture dry matter. The potentially digestible dry matter (DMpd) was estimated by the following equation (Paulino et al., 2008):

$$
\mathrm{DM} \text { pd }=0.98(100-\mathrm{NDF})+(\mathrm{NDF}-\mathrm{iNDF})
$$

in which: DMpd= potentially digestible dry matter; $\mathrm{NDF}=$ neutral detergent fiber and $\mathrm{iNDF}=$ indigestible neutral detergent fiber as $\%$ of dry matter.

The samples for qualitative evaluation of the pasture consumed by the animals were obtained through manual simulation of pasture every 14 days. The samples plus samples of concentrated food were evaluated for dry matter level, organic matter, crude protein, ether extract, acid detergent fiber and lignin following the techniques described by Silva \& Queiroz (2002). Neutral detergent fiber levels in diet were estimated according to recommendations by Mertens (2002). The corrections regarded to protein levels and ash in neutral detergent fiber were conducted following recommendation by Licitra et al. (1996) and Mertens (2002), respectively.

Non-fibrous carbohydrates of the supplements were estimated according to recommendations by Hall (2000), using the following equation:

$$
\begin{gathered}
\text { NFCcp }=100-[(\% \mathrm{~PB}-\% \mathrm{CPU}+\text { urea \% })+\% \text { NDFom(n) } \\
+\% \mathrm{EE}+\text { ash } \%)
\end{gathered}
$$

where: NFCcp $=$ non-fibrous carbohydrates corrected for protein and ash; NDFom $=$ Neutral detergent fiber correct for ashes and protein; EE = ether extract and $\mathrm{CPU}=$ crude protein from urea.

For evaluation of intake and digestibility of the consumed diet, starting on the $42^{\text {nd }}$ day of the experimental period, it was carried out a trial with duration of 9 days, in which six were for adaptation of the animals to the markers. Chromic oxide $\left(\mathrm{Cr}_{2} \mathrm{O}_{3}\right)$ was used to estimate fecal excretion and it was applied at $10 \mathrm{~g} / \mathrm{animal}$, via oral with the aid of an applicator always around at 9:00 a.m. Titanium dioxide $\left(\mathrm{TiO}_{2}\right)$ was used to estimate individual intake of the supplement, following the methodology describe by Titgemeyer et al. (2001). Titanium dioxide was mixed to the supplement at the quantity of $10 \mathrm{~g} / \mathrm{animal} /$ day right before the supplement supply so measurement of individual intake of the supplement could have been performed. Fecal collection was carried out on the seventh, eighth and ninth day at 3 p.m., 11 a.m. and 7 a.m., respectively aiming to obtain representative feces of each animal during the experimental period.

Feces were collected from the rectum or immediately after defecation of the animals in quantities approximately to 200 g every day. Those samples were identified per day and per animal, oven-dried $\left(55^{\circ} \mathrm{C}, 72\right.$ hours $)$ and grounded in knife mill with 1.0 -mm porosity sieve. The samples were composed based on weight dried on air, per animal, and they were stored in plastic pots properly sealed and identified.

Fecal excretion was estimated by considering the ratio between quantity of supplied marker and its concentration in the feces.

The estimate of supplement individual intake was obtained through the following equation:

$$
\text { IISup }=\mathrm{FE} \times \mathrm{iF} / \mathrm{iSup}
$$

where: IISup = supplement individual intake (kg/day); FE = fecal excretion (kg/day); $\mathrm{iF}=$ marker concentration in the feces $(\mathrm{g} / \mathrm{kg})$; iSup = marker concentration in the supplement $(\mathrm{g} / \mathrm{kg})$.

Estimate of voluntary intake of bulk dry matter was carried out by using as an intern marker the indigestible NDF by adjusting the equation proposed by Detmann et al. (2001):

$$
\operatorname{VIDM}(\mathrm{kg} / \text { day })=\{[(\mathrm{FE} \times \mathrm{CIF})-\mathrm{IS}] / \mathrm{CIFO}\}
$$

in which: VIDM = voluntary intake of bulk dry matter; FE = fecal excretion (kg/day); CIF = marker concentration in the feces ( $\mathrm{kg} / \mathrm{kg})$; IS = internal marker intake from the supplement $(\mathrm{kg} /$ day $)$ e CIFO = marker concentration in the forage $(\mathrm{kg} / \mathrm{kg})$.

Estimate of iNDF level in feces, in pasture samples obtained through pasture manual simulation and in the supplement was obtained after in situ incubation for 240 hours as suggested by Casali et al. (2008).

Digested dry matter intake was calculated by multiplying dry matter intake by the dry matter apparent digestibility coefficient. For digested neutral detergent fiber, it was calculated by multiplying the NDF intake by the NDF total digestibility coefficient.

The digestibility of ether extract was estimated according to Detmann et al. (2006).

On the last day of the digestibility trial, it was carried out a "spot" urine sample collection $(10 \mathrm{~mL})$, from spontaneous urination of the animals and blood sample collection approximately four hours after the supplement 
was given. After collection, the urine samples were diluted in $40 \mathrm{~mL}$ of $\mathrm{H}_{2} \mathrm{SO}_{4} 0.036 \mathrm{~N}$ (Valadares et al., 1999) and frozen at $-20^{\circ} \mathrm{C}$. For further quantification of levels of creatinine, urea and purine derivatives, blood samples were collected at the end of the urine collection period using tubes collection by vacuum with gel being the samples immediately centrifuged and the serum was frozen at $-20^{\circ} \mathrm{C}$.

The urine samples were analyzed for the creatine levels by using the method by Jaffé modified, for the urea and uric acid using the colorimetric-enzymatic method and the blood samples and for urea level using the same method for urine analyses. For those analyses, commercial kits were used.

The analyses of allantoin levels in the urine were done by using colorimetric method by Fujihara et al. (1987).

Daily urine volume was estimated by using the ratio between daily excretion of creatinine (CE), adopting as a reference the equation proposed by Chizzotti et al. (2006), and its concentration in the spot samples:

$$
\mathrm{EC}_{(\mathrm{mg} / \mathrm{kgPC})}=32.27-0.01093 \times \mathrm{PC}
$$

Therefore, the daily urinary excretion of the nitrogen compounds was the product among its concentration in the "spot" samples and the estimate value of the urinary volume.

For estimate of total excretion of purine derivatives, allantoin was added to uric acid excreted by urine, expressed in $\mathrm{mmol} /$ day.

The absorbed urine ( $\mathrm{Y}, \mathrm{mmol} / \mathrm{day})$ were calculated from the excretion of purine derivatives ( $\mathrm{X}, \mathrm{mmol} /$ day), by using the following equation:

$$
\mathrm{Y}=\left(\mathrm{X}-0.385 \mathrm{PC}^{0.75}\right) / 0.85
$$

in which: $0.85=$ recovery of absorbed urine with derivatives of purine and $0.385 \mathrm{PC}^{0.75}=$ the endogenous contribution for excretion of purines (Verbic et al., 1990).

The rumen synthesis of nitrogen compounds ( $\mathrm{Y}, \mathrm{g}$ $\mathrm{Nmic}$ /day) was calculated in function of absorbed purines (X, mmol/day) by using the equation described by Chen \& Gomes (1992), except for the relation N purine: $N$ bacteria total of 0,134 following Valadares et al. (1999):

$$
\mathrm{Y}=70 \mathrm{X} /(0.83 \times 0.134 \times 1000)
$$

in which: $70=$ purine $\mathrm{N}$ contend $(\mathrm{mgN} / \mathrm{mol}) ; 0.134=$ the relation purine $\mathrm{N}$ :total bacterial $\mathrm{N}$; and $0.83=$ the digestibility of bacterial purine.

The statistical procedures were performed by using the computer program SAS, adopting 0.10 as probability critical level for the type I error. Comparisons among the observed means were carried out by using decomposition of the square sum for supplements in orthogonal contrasts related to comparison among supplementation and no supplementation and to the linear effect, cubical and quadratic for the levels of substitution of soybean meal for cottonseed meal 38\%.

\section{Results and Discussion}

The total dry matter available to the animals were always higher than 7.0 to $11.0 \%$ of the body weight of the animals in dry matter, considered by Barbosa et al. (2006) as needed to guarantee the maximum intake of forage, the lowest grazing time and the greatest quantity of forage degraded in the rumen (Table 2).

According to Paulino et al. (2008), the interpretation of forage available for grazing as basal nutritional resource has to be conducted under the optics of potentially convertible fraction, which can be reached by applying the concept of potentially digestible dry matter, because this one integrates quantity and quality regardless to the year season. The average availabilities of dry matter and potentially digestible dry matter throughout the experimental period were $4,328.3$ and $2,858.4 \mathrm{~kg} / \mathrm{ha}$, respectively (Table 2).

In this study, the reasoning was made based in the pasture potentially digestible dry matter, whose suggestion made by Paulino et al. (2002) would be the offer of 4 to $5 \%$ of the animals body weight in dry matter to obtain a satisfactory performance of the animals raised in pasture. The potentially digestible dry matter availability expressed in function of the body weight refers the quantitative and qualitative idea of forage momently available to the animal, regardless to the stocking rate (Valente, 2009). In this study the potentially digestible dry matter availability as body weight percentage was $5.78 \%$. The greatest the availability and quality of the basal forager resource, the lowest was the necessity to add externals resources to the system to optimize animal production and the greatest the economical efficiency of the system.

The Brachiaria decumbens obtained through simulated pasture had crude protein average level of $7.66 \%$ (Table 3), which means that it is within the range 7-8\% of crude protein in the basal diet reported by Lazzarini et al. (2009) as needed to have suitable use of the neutral detergent fiber of the low quality basal forage, which is the main energy source for animals raised in pastures. However, if it is below the $10 \%$ reported by Sampaio et al. (2009), it is optimum to maximize pasture intake.

Table 2 - Total dry matter and potentially digestible dry matter availability during the experimental periods

\begin{tabular}{lcc}
\hline Period & DM & DMpd \\
\cline { 2 - 3 } & & t/ha \\
\hline First & 5.26 & 3.51 \\
Second & 4.80 & 3.27 \\
Third & 2.95 & 1.81 \\
Average & 4.33 & 2.86 \\
\hline
\end{tabular}


Although the forage consumed by the animals had crude protein level higher than the minimum needed so there is appropriate use of the neutral detergent fiber (NDF) of the low quality basal forage, it was verified that $28.65 \%$ of this protein was lowly available for the animal, in other words, in insoluble neutral protein form (NDICP; Table 3), which reinforces the importance of supplying nitrogen supplement sources more rapidly available. Because forage is the most economic and feasible way of feeding bovines, to increase the use of forage through optimization of intake and availability of its nutrients is primordial (Sales et al., 2009).

Animals that received supplementation had daily average gain higher than the animals which did not receive supplementation $(\mathrm{P}<0.10$; Table 4$)$. Among the levels of substitution of soybean meal for cottonseed meal 38\%, there was no difference among daily average gain of the animals.

It was noted greater intake of crude protein and NFC $(\mathrm{P}<0.10)$ for animals who received supplementation than the animals that did not receive supplementation; because the levels of these nutrients are fairly low in the basal forage, it was expected that there would be a significant increase in its intake with the supply of supplement sources.
Among the levels of substitution of soybean meal by cottonseed meal $38 \%$ it was not observed effect on the nutrient intake, except for NFC intake, which showed cubic behavior (Table 5).

The requirements of crude protein and TDN by Zebu heifers with body weight of $250 \mathrm{~kg}$ and daily average gain of 500 grams are $602.44 \mathrm{~g} /$ day and $3.19 \mathrm{~kg} /$ day, respectively (Valadares Filho, 2006).

For all the supplements, the TDN intake was higher than requirements by Zebu heifers from this category to accept daily average gain close to $500 \mathrm{~g}$. Considering the crude protein intake, the supplements $\mathrm{CS}_{0}, \mathrm{CS}_{33}, \mathrm{CS}_{67}$ and $\mathrm{CS}_{100}$ permitted a crude protein intake equal to or higher than the needed one to accept the same daily average gain previously cited. The low intake of crude proteins by the animals from the control treatment injured the daily average gain, a fact that can be proved by the lower daily average gain of these animals.

Supplementation increased the coefficient of total apparent digestibility of crude protein and NFC. The intake of NDFom(n) was not affected by supplementation (Table 4); however, because fiber of meals is more digestible (Sales et al., 2009), there was an increase of total apparent digestibility of this component (Table 6), without affecting

Table 3 - Chemical composition of the supplements and of Brachiaria decumbens

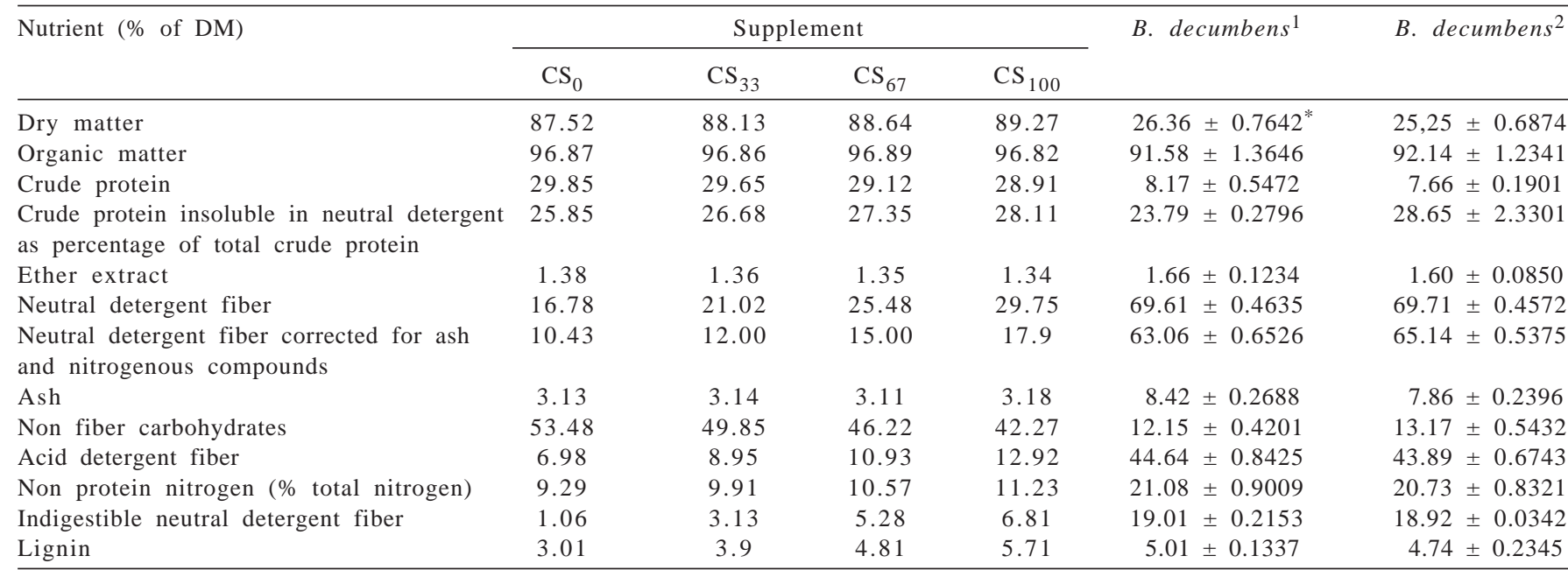

${ }^{1}$ Sample of simulated pasture obtained during all the experimental period.

2 Sample of the simulated grazing carried out during evaluation of nutritional traits.

* Mean standard error.

Table 4 - Descriptive levels of probability of contrast among supplemented and no supplemented, regression parameters, initial body weight means, final body weight and daily average gain in for different supplements

\begin{tabular}{|c|c|c|c|c|c|c|c|c|c|c|}
\hline \multirow[t]{2}{*}{ Item } & \multicolumn{5}{|c|}{ Supplement } & \multirow[t]{2}{*}{ CV (\%) } & \multicolumn{4}{|c|}{ Value - $\mathrm{P}^{2}$} \\
\hline & MM & $\mathrm{CS}_{0}$ & $\mathrm{CS}_{33}$ & $\mathrm{CS}_{67}$ & $\mathrm{CS}_{100}$ & & $\mathrm{CO}$ & Linear & Quadratic & Cubic \\
\hline Initial body weight (kg) & 251.1 & 249.2 & 251.1 & 248.0 & 249.7 & & & & & \\
\hline Final body weight $(\mathrm{kg})$ & 283.0 & 295.7 & 297.7 & 293.9 & 295.4 & 2.7 & 0.0008 & 0.7284 & 0.9284 & 0.4275 \\
\hline Average daily weight gain (g) & 397 & 546 & 570 & 525 & 542 & 18.4 & 0.0008 & 0.7264 & 0.9310 & 0.4238 \\
\hline
\end{tabular}


Table 5 - Adjusted means, coefficients of variation, and significance of effects for voluntary intake according to cottonseed meal 38\% levels in the supplements



${ }_{1} \mathrm{NDFom}(\mathrm{n})=$ neutral detergent fiber corrected for ash and nitrogenous compounds.

$2 \hat{Y}=1.3000+0.0251 x-0.000614 x^{2}+0.000003 x^{3}\left(R^{2}>0.9999\right)$

Table 6 - Adjusted means, coefficients of variation, and significance of effects for digestibility coefficients and total digestible nutrients levels according to the cottonseed meal 38\% levels in the supplements

\begin{tabular}{|c|c|c|c|c|c|c|c|c|c|c|}
\hline \multirow[t]{2}{*}{ Item } & \multicolumn{5}{|c|}{ Supplement } & \multirow[t]{2}{*}{ CV (\%) } & \multicolumn{4}{|c|}{ Value - $\mathrm{P}^{2}$} \\
\hline & MM & $\mathrm{CS}_{0}$ & $\mathrm{CS}_{33}$ & $\mathrm{CS}_{67}$ & $\mathrm{CS}_{100}$ & & $\mathrm{CO}$ & Linear & Quadratic & Cubic \\
\hline Dry matter ${ }^{1}$ & 63.69 & 61.73 & 61.96 & 64.40 & 63.97 & 3.1 & 0.4165 & 0.0008 & 0.6512 & 0.1322 \\
\hline Organic matter ${ }^{2}$ & 64.98 & 63.35 & 62.76 & 65.68 & 66.78 & 4.1 & 0.6112 & 0.0057 & 0.4044 & 0.2392 \\
\hline Crude protein ${ }^{3}$ & 46.66 & 49.39 & 49.91 & 56.15 & 57.16 & 9.7 & 0.0045 & 0.0015 & 0.8995 & 0.2062 \\
\hline Ether extract & 75.24 & 75.80 & 74.86 & 74.73 & 75.43 & 1.9 & $<0.0001$ & $<0.0001$ & $<0.0001$ & 0.1984 \\
\hline $\operatorname{NDFom}(n)^{4,5}$ & 66.52 & 63.36 & 63.71 & 64.96 & 66.51 & 3.1 & 0.1977 & 0.0217 & 0.5490 & 0.8974 \\
\hline Non-fibrous carbohydrates 6 & 58.15 & 61.80 & 66.29 & 64.85 & 70.31 & 5.9 & $<0.0001$ & 0.0009 & 0.7411 & 0.0578 \\
\hline Total digestible nutrients $^{7}$ & 63.91 & 64.77 & 64.39 & 65.74 & 66.36 & 3.2 & 0.1241 & 0.0957 & 0.5346 & 0.4941 \\
\hline
\end{tabular}

$1 \hat{Y}=61.6393+0.0275 \times\left(r^{2}=0.4946\right)$.

$2 \hat{Y}=62.6626+0.0396 x\left(r^{2}=0.8040\right)$.

$3 \hat{Y}=48.7260+0.0886 \times\left(r^{2}=0.8781\right)$.

${ }^{4} \operatorname{NDFom}(\mathrm{n})=$ neutral detergent fiber correct for ash and nitrogenous compounds.

$5 \hat{Y}=63.03021+0.03179 x\left(r^{2}=0.0521\right)$.

$6 \hat{Y}=61.8028+0.3519 x-0.00844 x^{2}+0.000057 x^{3}\left(R^{2}>0.9999\right)$.

$7 \hat{Y}=64.40207+0.01835 \times\left(r^{2}=0.7713\right)$.

dry matter intake, as the greatest influence on this trait is exercised by pasture neutral detergent fiber.

The apparent digestibility of crude protein was higher for animals that received supplementation. In addition to the dilution effect of the fecal metabolic dilution resulted from the intake of this fraction (Table 5), the apparent digestibility of the protein can be increased for more loses of the rumen nitrogen.

Among the levels of substitution of soybean meal by cottonseed meal 38\%, it was observed a linear positive effect on the total apparent digestibility coefficient of dry matter, organic matter, crude protein and TDN, indicating an improvement of the ruminal environment of the microbial activity. Costa et al. (2008) noted average increase of $22.4 \%$ in the microbial increase on the fiber carbohydrates of the low quality forage according to nitrogen compounds of the supplementation.

The coefficient of digestibility of ether extract was not affected $(\mathrm{P}>0.10)$ by the supplementation and by the level of cottonseed meal $38 \%$ in the supplements either, probably because of the low level of ether extract in the supplements and in the forage consumed by the animals (Table 3). 
The non-fibrous carbohydrates intake showed a cubic effect; nevertheless, the supervision of the behavior of the means of this variable suggest linear-response-plateau behavior (LRP; Table 7). The adjustment of a LRP function for this variable permitted to evidence an increase on the NFC intake to limits close to 2-3\% of cottonseed meal 38\% substituting soybean meal when stabilization of the estimate was noted (Table 7). This kind of answer suggests that the observed effect is because of the inclusion of cottonseed meal 38\% in the supplements and not because of the level of this supplement.

Valadares et al.(1997) suggested that the plasmatic levels of $\mathrm{N}$-urea ranging from 13.52 and $15.15 \mathrm{mg} / \mathrm{dL}$ corresponds to the maximum microbial efficiency and it probably would be the limit in which there is loss of protein for Zebu heifers fed $62.5 \%$ TDN. In this study, the average value of UNS for animals who received supplementation was $8.29 \mathrm{mg} / \mathrm{dL}$, a value which is quite below the one cited by Valadares et al. (1997) for maximum microbial efficiency. However, the average of UNS for animals which did not receive supplementation was even lower than $6.78 \mathrm{mg} /$ day (Table 8), a value much lower than the one for supplemented animals, indicating a possible restrain of microbial activity which could have harmed the performance of non supplemented animals.
There was no $(\mathrm{P}>0.10)$ difference in the efficiency of microbial protein synthesis by kg of TDN (EFM) among supplemented and no supplemented animals, neither there was $(\mathrm{P}>0.10)$ difference among the EFM of the animals receiving different levels of cottonseed meal $38 \%$. Possibly because of the quality forage, the consumption of nutrients and energy met the requirement of ruminal microorganisms, including animals that received only mineral mixture, which contributed for those results. Therefore, it is believed that there was a good synchronization among offer and demand of energy and protein in the rumen environment. There were no differences regarded to the EFM for the different supplements.

Values of urinary excretion of ureic nitrogen (UEUN) indicate that the absolute quantity of nitrogen is lost without being properly used by the animal. It was not noted differences $(\mathrm{P}<0.10$; Table 8$)$ in the UEUN among supplemented and no supplemented animals, neither it was observed differences in the UEUN among cottonseed meal $38 \%$ replacing soybean meal.

Apparent nitrogen compound balance (Table 8) differed $(\mathrm{P}<0.10)$ among supplemented and no supplemented animals. This variable followed the behavior of variables of nitrogen consumption and the nitrogen fecal excretion,

Table 7 - Parameterization of non fiber carbohydrate intake related to levels of cottonseed meal 38\% in the supplements accordingly to linea response- plateau type equations

\begin{tabular}{|c|c|c|c|c|c|}
\hline \multirow[b]{2}{*}{ Item } & \multicolumn{2}{|c|}{ Linear Phase } & \multicolumn{3}{|c|}{ Plateau } \\
\hline & Intercept & Slope coeficient & CS $^{1}$ level & Estimate & $\mathrm{S}_{\mathrm{xy}}^{2}$ \\
\hline Non fiber carbohydrate & 1.3000 & 0.009 & 2.5603 & 1.3225 & 0.1379 \\
\hline
\end{tabular}

Table 8 - Adjusted means, coefficients of variation, and significance of effects for nitrogenous compounds metabolism according to the cottonseed levels in the supplements

\begin{tabular}{|c|c|c|c|c|c|c|c|c|c|c|}
\hline \multirow[t]{2}{*}{ Item } & \multicolumn{5}{|c|}{ Castor seed meal level (\%) } & \multirow[t]{2}{*}{$\mathrm{CV}(\%)$} & \multicolumn{4}{|c|}{ Value - $\mathrm{P}^{2}$} \\
\hline & $\mathrm{MM}$ & $\mathrm{CS}_{0}$ & $\mathrm{CS}_{33}$ & $\mathrm{CS}_{67}$ & $\mathrm{CS}_{100}$ & & $\mathrm{CO}$ & Linear & Quadratic & Cubic \\
\hline Nitrogen intake (g/dia) & 88.95 & 125.14 & 125.86 & 127.23 & 128.80 & 14.7 & $<0.0001$ & 0.6762 & 0.9491 & 0.9873 \\
\hline Nitrogen fecal excretion (g/day) ${ }^{1}$ & 43.99 & 63.24 & 62.99 & 55.76 & 54.96 & 15.2 & 0.0002 & 0.0340 & 0.9332 & 0.3607 \\
\hline Ureic nitrogen urinary excretion (g/day) & 7.44 & 9.09 & 7.21 & 8.76 & 8.74 & 23.1 & 0.2485 & 0.8807 & 0.2072 & 0.1316 \\
\hline $\begin{array}{l}\text { Apparent nitrogen balance (g/day regarded to } \\
\text { consumed } \mathrm{N})^{2}\end{array}$ & 37.52 & 52.80 & 55.65 & 62.71 & 65.10 & 20.7 & $<0.0001$ & 0.0292 & 0.9570 & 0.6462 \\
\hline $\begin{array}{l}\text { Apparent nitrogen balance expressed in g/day } \\
\text { regarded to consumed } \mathrm{N}^{3}\end{array}$ & 0.389 & 0.419 & 0.440 & 0.492 & 0.502 & 12.3 & 0.0058 & 0.0033 & 0.8042 & 0.4553 \\
\hline Serum ureic nitrogen concentration $(\mathrm{mg} / \mathrm{dL})^{4}$ & 6.78 & 8.11 & 7.67 & 8.47 & 8.92 & 11.9 & 0.0015 & 0.0551 & 0.2235 & 0.3345 \\
\hline Flow of microbial nitrogen compounds (g/day) & 85.42 & 85.44 & 83.85 & 88.03 & 87.17 & 15.6 & 0.9087 & 0.6818 & 0.9432 & 0.6363 \\
\hline NMICR $^{5}$ & 9.89 & 6.90 & 6.75 & 7.02 & 6.98 & 19.9 & 0.0001 & 0.8823 & 0.9556 & 0.7602 \\
\hline Purine derivative excretion (mmol/day) & 141.7 & 141.4 & 138.6 & 145.1 & 144.1 & 12.9 & 0.9426 & 0.6496 & 0.8966 & 0.6017 \\
\hline Microbial synthesis efficiency (g microbial CP/kg TDN) & 117.6 & 119.9 & 122.2 & 125.0 & 121.5 & 18.4 & 0.6556 & 0.8433 & 0.7346 & 0.8595 \\
\hline
\end{tabular}

$1 \hat{Y}=64.0555-0.0962 \times\left(r^{2}=0.8503\right)$

$2 \hat{Y}=52.4740+0.1318 \times\left(r^{2}=0.9602\right)$

$3 \hat{Y}=0.4190+0.0008 x\left(r^{2}=0.9457\right)$.

$4 \hat{Y}=7.8079+0.0096 x\left(r^{2}=0.6139\right)$

${ }^{5}$ Flow of microbial nitrogen compound regarded to consumed nitrogen (g/g of consumed N). 
which were lower for non-supplemented animals. There was a reduction $(\mathrm{P}<0.10)$ in the nitrogen fecal excretion as the level of cottonseed meal 38\% increased in the supplements. There was a positive linear effect $(\mathrm{P}<0.10)$ by the level of cottonseed meal $38 \%$ on the nitrogen compound balance in which it could be seen a greater retention of the dietary nitrogen with the cottonseed meal 38\% in supplements.

\section{Conclusions}

Supplementation of beef heifers under pasture during the rainy period increases productive performance. The use of cottonseed meal 38\% in multiple supplements for heifers substituting the soybean meal result in the same productive performance.

\section{References}

ANUAlPeC. 2007. Anuário da Pecuária Brasileira. São Paulo: Instituto FNP, 2007. 368p.

BARBOSA, M.A.A.F.; NASCIMENTO JÚNIOR, D.; CECATO, U Dinâmica da pastagem e desempenho de novilhos em pastagem de capim tanzânia sob diferentes ofertas de forragem. Revista Brasileira de Zootecnia, v.35, n.4, p.1594-1600, 2006 (supl.)

CASALI, A.O.; DETMANN, E.; VALADARES FILHO, S.C. et al. Influência do tempo de incubação e do tamanho de partículas sobre os teores de compostos indigestíveis em alimentos e fezes bovinas obtidos por procedimentos in situ. Revista Brasileira de Zootecnia, v.37, n.2, p.335-342, 2008.

CHEN, X.B.; GOMES, M.J. Estimation of microbial protein supply to sheep and cattle basid on urinary excretion of purine derivatives-an overview of the technical details. Ocasional publication. Buchsburnd Aberdeen: Rowett Research Institute, 1992. 21p.

CHIZZOTTI, M.L.; VALADARES FILHO, S.C.; VALADARES, R.F. et al. Consumo, digestibilidade, excreção de uréia e derivados de purina em novilhas de diferentes pesos. Revista Brasileira de Zootecnia, v.35, p.1813-1821,2006.

COSTA, V.A.C.; DETMANN, E.; VALADARES FILHO, S.C. et al. Degradação in vitro da fibra em detergente neutro de forragem tropical de baixa qualidade em função de suplementação com proteína e/ou carboidratos. Revista Brasileira de Zootecnia, v.37, n.3, p.494-503, 2008.

DETMANN, E.; PAULINO, M.F.; ZERVOUDAKIS, J.T. et al. Cromo e indicadores internos na estimação do consumo de novilhos mestiços, suplementados, a pasto. Revista Brasileira de Zootecnia, v.30, n.5, p.1600-1609, 2001.

DETMANN, E.; VALADARES FILHO, S.C.; PINA, D.S. et al. Estimação da digestibilidade do extrato etéreo em ruminantes a partir dos teores dietéticos: desenvolvimento de um modelo para condições brasileiras. Revista Brasileira de Zootecnia, v.35, n.4, p.1469-1478, 2006.

DETMANN, E.; PAULINO, M.F.; VALADARES FILHO, S.C. Avaliação nutricional de alimentos ou dietas? Uma abordagem conceitual. In: SIMPÓSIO DE PRODUÇ̃̃O DE GADO DE CORTE, 6., SIMPÓSIO INTERNACIONAL DE PRODUÇÃO DE GADO DE CORTE, 2., 2008, Viçosa, MG. Anais... Viçosa, MG: UFV, 2008. p.21-52.

FUJIHARA, T.; ØRSKOV, E.R.; REEDS, P.J. et al. The effect of protein infusion on urinary excretion of purine derivatives in ruminants nourished by intragastric nutrition. The Journal of Agricultural Science, v.109, n.1, p.7-12, 1987.
HALL, M.B.; AKINYODE, A. Cottonseed hulls: working with with a novel fiber source. In: ANNUAL FLORIDA RUMINANT NUTRITION SYMPOSIUM, 11., 2000, Gainesville. Proceedings... Gainesville, 2000. p.179-186.

LAZZARINI, I.; DETMANN, E.; SAMPAIO, C.B. Intake and digestibility in cattle fed low-quality tropical forage and supplemented with nitrogenous compounds. Revista Brasileira de Zootecnia, v.38 n.10 p.2021-2030, 2009.

LICITRA, G.; HERNANDEZ, T.M.; VAN SOEST, P.J. Standardization of procedures for nitrogen fractionation of ruminant feeds. Animal Feed Science and Technology, v.57, n.4, p.347-358, 1996.

MERTENS, D.R. Gravimetric determination of amylase-treated neutral detergent fiber in feeds with refluxing in beaker or crucibles: collaborative study. Journal of AOAC International, v.85, p.1217-1240, 2002

NUVITAL. O algodão na nutrição de bovinos. Disponível em http: <//www.nuvital.com.br > Acesso em: 2/2/2009.

PAULINO, M.F.; ZERVOUDAKIS, J.T.; MORAES, E.H.B.K. et al. Bovinocultura de ciclo curto em pastagens. In: SIMPÓSIO DE PRODUÇÃO DE GADO DE CORTE, 3., 2002, Viçosa, MG. Anais... Viçosa, MG: UFV, 2002. p.153-196.

PAULINO, M.F.; DETMANN, E.; VALADARES FILHO. S.C. Suplementação animal em pasto: energética ou protéica? In: SIMPÓSIO SOBRE MANEJO ESTRATÉGICO DA PAStAGEM, 3., 2006, Viçosa, MG. Anais... Viçosa, MG: SIMFOR, 2006. p.359-392.

PAULINO, M.F.; DETMANN, E.; VALADARES FILHO, S.C. Bovinocultura funcional nos tópicos. In: SIMPÓSIO DE PRODUÇÃO DE GADO DE CORTE, 6., SIMPÓSIO INTERNACIONAL DE PRODUÇÃO DE GADO DE CORTE, 2., 2008, Viçosa, MG. Anais... Viçosa, MG: VI SIMCORTE, 2008. p.275-305.

SALES, M.F.L.; PAULINO, M.F.; VALADARES FILHO, S.C. et al. Composição corporal e requisitos energéticos de bovinos de corte sob suplementação em pastejo. Revista Brasileira de Zootecnia, v.38, n.7, p.1355-1362, 2009.

SAMPAIO, C.B.; DETMANN, E.; LAZZARINI, I. Rumen dynamics of neutral detergent fiber in cattle fed low-quality tropical forage and supplemented with nitrogenous compounds. Revista Brasileira de Zootecnia, v.38, n.3, p.560-569, 2009.

SILVA, D.J.; QUEIROZ, A.C. Análise de alimentos: métodos químicos e biológicos. 3.ed. Viçosa, MG: UFV, 2002. 235p.

TITGEMEYER, E.C.; ARMENDARIZ, C.K.; BINDEL, D.J. et al. Evaluation of titanium dioxide as a digestibility marker for cattle. Journal of Animal Science, v.79, p.1059-1063, 2001.

VALADARES FILHO, S.C.; PAULINO, P.V.R.; MAGALHÃES, K.A. Exigências nutricionais de zebuínos e tabelas de composição de alimentos BR-CORTE. 1.ed. Viçosa, MG: UFV, DZO, 2006. 142p.

VALADARES, R.F.D.; BRODERICK, G.A.; VALADARES FILHO, S.C. et al. Effect of replacing alfalfa silage with high moisture corn on ruminal protein synthesis estimated from excretion of total purine derivatives. Journal of Dairy Science, v.82, n.11, p.2686-2696, 1999.

VALADARES, R.F.D.; GONÇALVES, L.C.; SAMPAIO, I.B. et al. Níveis de proteína em dietas de bovinos. 2. Consumo, digestibilidade e balanço de compostos nitrogenados. Revista Brasileira de Zootecnia, v.26, n.6, p.1259-1263, 1997.

VALENTE, E.E.L. Suplementação de bezerras de corte lactentes e em recria e parâmetros nutricionais de vacas de corte em pastejo. 2009. 73f. Dissertação (Mestrado em Zootecnia) - Universidade Federal de Viçosa, Viçosa, MG.

VERBIC, J.; CHEN, X.B.; MACLEOD, N.A. et al. Excretion of purine derivatives by ruminants. Effect of microbial nucleic acid infusion on purine derivative excretion by steers. Journal of Agricultural Science, v.114, n.3, p.243-248, 1990. 